\title{
THE INFLUENCE OF STORE ATMOSPHERE AND SALESPROMOTION ON PURCHASING DECISIONS (SURVEY ON SUPERMARKET HAPPY SUNGGAL)
}

\author{
Efry Kurnia \\ Faculty of Economic and Business \\ University of Muhammadiyah Sumatera Utara \\ efrikurnia@umsu.ac.id
}

\begin{abstract}
The purpose of this quantitative descriptive explanatory survey study was to find out the of store atmosphere and sales promotion towards purchasing decisions. This research was conducted at the Supermarket, located in the region Happy Sunggal Right near the housing complex of Sri Gunting in Sunggal. This research is quantitative deskriptif research study explanatory with the nature of research that is supported by the survey. Research using a sample of 100 people as respondents who shopped in the supermarkets Happy more than 2 times. Sampling in accidental sampling. The technique of data collection is done with the study documentation and disseminate a list of questions. This research uses techniques of data analysis by using multiple linear regression analysis. The results of this research show the store atmosphere is positive but not significant effect against the purchasing decisions of consumers shopping in the supermarkets Happy seen from the visits of buyers that are not changed in the buying decisions at the supermarket. Sales Promotion of positive and significant effect on the purchasing decision. The variable sales promotion has a strong influence in attracting consumers to purchase or shopping in the supermarkets Happy.
\end{abstract}

Keywords: Store Atmosphere, Sales Promotion, Purchase Decision

\section{INTRODUCTION}

An increase in the needs of the constantly changing give a sign higher desire more than just trade off product. The influence of the great environment gives a very big opportunity for the consumer in deciding what it wants to be bought. Environment with a good layout and convenient of course will give you the tranquility and a feeling of happy visitors in any shopping. Furthermore, with the atmosphere of a cozy store will affect consumers in considering to buy. Kotler (2001) mention the atmosphere (atmosphere outlets) are planned to suit the mood of the market goals and that can attract consumers to buy and be satisfied. The spacious and quiet atmosphere with the arrangement of the items within easy reach for consumers will also give rise to a feeling of being happy for consumers and customers to decide to buy. Setup, mood, voice, scent, color and visual communication in the supermarket will arouse a feeling of fun and satisfaction in giving consumers confidence to buy.

Every activity product offerings to consumers should always be coupled with services that provide satisfaction and sense of comfort. Happy feelings of consumers can only cause desire buy from unplanned. Consumers always expect something a product that has more advantages compared to other similar products or types of products. Natalia and Mumuh Mulyana (2014) in its research also holds sales promotions is a direct inducement or incentive that offers more value for a product to the consumer. Promotion - promotion of a good to the consumer will attract customers in considering a decision to buy.

There are approximately 22 existing supermarkets in the city of Medan and 3 types of supermarkets operating in the regions Sunggal Medan North Sumatra, that Toserba, Supermarket and supermarkets 88 and Happy Supermarkets. Three of these have special self-service respectively. Start with the completeness of the item, the price and promo offered allegiance ahead of the big day or some days. Every year in the city of Medan supermarket always give a price quote and a new product that is acceptable and high response got from the public. The public need not go far to the city center to get all the household appliances and transport cost and prices of products the goods which are usually more expensive. There is a supermarket in the city of Medan, many offer a variety of products tools 
household with fixed on the decision of consumers to purchase by choosing at competitive rates as well as a promotional offer made by a supermarket. Through self-service site placement to all activities of other offers to the public, self-service supermarket-growing and thriving community of trying to give the price acceptable and affordable by the community. Other services are also very special is the area that can be visited by families and guarded parking area free of charge, this is what makes consumers happy to linger and also be comfortable for shopping. For that it takes events on sustainable utilization in order for self-service convenience particularly Happy at being a prima donna with self-service Sunggal fulfillment of the needs and desires of the community that continue to increase each time.

\section{RESEARCH PURPOSE}

To know and analyze the influence of store atmosphere on purchasing decisions and to know the influence of sales promotions on purchasing decisions to consumer Supermarkets Happy in Srigunting.

\section{RESEARCH QUESTIONS}

Based on the background describe then the research questions are:

1. Is there any influence of store atmosphere on purchase decisions?

2. Is there any influence of sales promotion on purchase decisions?

\section{A THEORITICAL FRAMEWORK}

\section{Store Atmosphere}

Store Atmosphere (atmosphere of the store) is a combination of physical characteristics like the architecture, layout, lighting, bulletin board postings, color, temperature, music, scents thoroughly will create images in the form of the consumer ". Through the atmosphere of the shop is accidentally created by retail. Retail is attempting to communicate the information associated with the service, price or availability of merchandise that is both fashionable (Utami, 2010).

Atmosphere related to how managers can manipulate the design of buildings, interior space, the space of the halls, the texture of the carpet and walls, smells, colors, shapes and sounds experienced by those customers who all aim to achieve a certain influence. Even the arrangement of goods, kinds of exhibitions/performances, and pose the dolls can affect consumer perception upon the atmosphere of the shop (Mowen \& Minor 2002)

Store Atmosphere has elements all of which affect the atmosphere of the shop who wanted to created. Elements of the store's atmosphere consists of exterior, interior, general store layout, and interior displays. According to Berman and Evan (2001) split the elements of store atmosphere into the 4 elements:

1. Exterior (the front of the store)

The front of the store is a part of training users. Then he should give the impression of interest. With reflecting stability and robustness, then the front and outside it can create trust and goodwill. In addition, it should show the spirit of the company and the nature of the activity that is in it. Because the front part and the exterior serves as identification or recognition marks then preferably installed symbols.

\section{General interior}

Various motives of the consumer enter the store, he should acquire a pleasant impression. This effect can be created for example with the color of the walls of the store are interesting, the music that is played, as well as the scent/smell and air fields stores.

\section{Store layout.}

A plan to determine the specific location and setting of the street/alley inside the store which is pretty wide and makes it easy for people to pass ply, and stores such as completeness of the locker room is nice and comfortable. 
4. Interior display

Crucial for the atmosphere of the store because it gives information to the consumer. Its main purpose is to improve sales and profit for the store. The interior display is included: posters, signs, display location instructions items on special days such as new year and Idul fitri holiday.

\section{Sales Promotion}

Sales promotion is a marketing activity in addition to sales by individuals, advertensi, and publicity, which encourages consumers to buy and drive the success of the dealer, such as display, shows, exhibitions, demonstrations, semental ran, as well as various business sales which is not continuous and not carried out routinely. Sales promotion is a form of persuasion directly through the use of various incentives that can be set up to stimulate the purchase of products immediately and/or increase the amount of goods bought customers, (Kotler, 2008).

\section{Purchase Decision}

Setiadi (2003) stated that the definition of decision making is a process of integration that combines the knowledge to evaluate two or more alternative behavior and choose one of them. The result of this integration process is an option, presented as cognitively desire behave.

The buyer's decision to purchase or select a specific product does not come with it. Know your buying decision a particular product that consists of five stages. If employers want to successfully sell their products, they have to actively influence the buyers about the advantages, benefits and prices of their products in every stage of the decision-making process. Efforts to affect potential buyers all the more necessary in the case of marketing of goods or services, i.e. the product of very high price per unit. Efforts to affect the decision of the buyer on the stages of decision making is also required in the case of the purchase of capital goods (capital goods) and technology (technological/management assistances). The buyer takes a lot of effort and time to gather and analyze information about products that would like to purchase. To fund the purchase of exclusive products often required more than one source of funding, including private equity, financial leasing and credit from banks.

Thus, the process of buying decisions become more complex. When necessary (especially in the transaction of purchasing capital goods) manufacturers are expected to find buyers willing to help external funding sources to fund the product to be purchased. The following consumer decision process images which can be seen below:

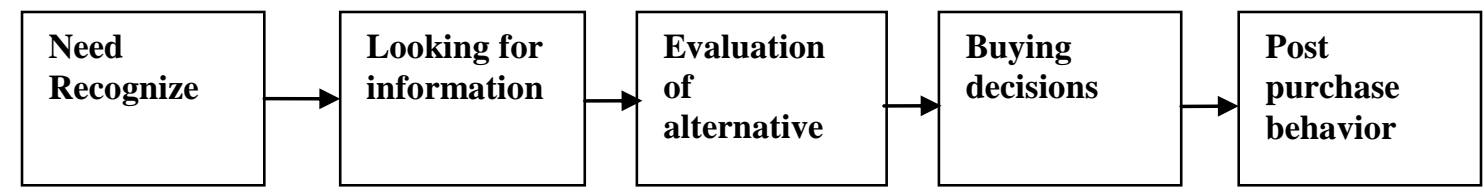

Figure 1. The purchase decision process

As for the fifth stage of the decision-making process of buying are as follows:

\section{Need Recognition}

According to Peter and Donnelly (2004), States the introduction of the requirement for products is the point of leaving the decision-making process buy. Introduction the need for a particular product can be powered by a variety of internal and external factors. Examples of internal factors that spur the end consumer needs are hunger, thirst, and so on. Because hungry consumers need food. Because feeling sick they need hospital services and drugs. According to a theory of motivation that much known is Abraham Maslow's theory of motivation in Asnawi (2007) divides into several kinds of needs, including:

a. Physiological Needs

b. Protection from something that is feared.

c. Award.

d. Self-Development.

2. Collection of information about the product (Alternative Search for Information)

The following consumer decision process images which can be seen below: 
According to Kliensteuber and Sutojo (2007), the buyer has a minimum of 4 sources of information about the products they buy. A fourth source of information is as follows:

a. Internal sources of information (personal experience)

b. Source of information on groups (family, relatives, neighbours)

c. Sources of commercial information (representative offices, sales executive)

d. Public information sources (advertisements, brochures, leaflets)

3. The analysis of a wide range of information successfully collected (Alternative evaluation of information) the buyer used the results of the analysis of a wide range of information about the products they gather as one consideration of dropping the choice. The analysis of the information itself is done through a specific procedure. The first step in the analysis is to compare the information about the superiority of the attributes or benefits of each type of product, compared to rival products attribute. The second step of analysis information is compiled a list of options.

\section{Purchase decision}

When the results of the analysis of the information already assured, then the consumers can decide to purchase or not a product.

2. Past Purchase Evaluation

Evaluation is important for the buyer, because with the evaluation after the purchase, the buyer will later decide to purchase or not in the future.

From the explanation above, the framework of this research can be described as follows:

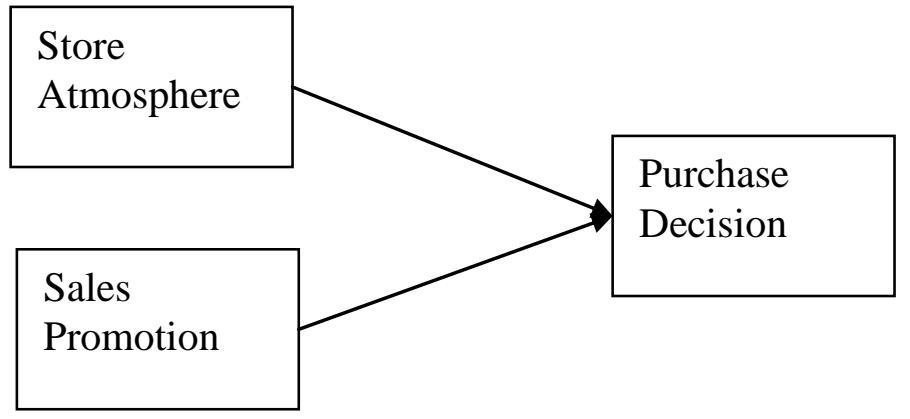

Figure 2: Research Model

\section{RESEARCH METHODS}

\section{Populations and Samples}

According to Sugiyono (2015) population is the generalization of the object or the subject which has certain qualities and characteristics set by the researchers to learn and then drawn the conclusion. The average visit self-service range 35-60 visitors per day excluding holidays and the big day can achieve ranges 115-120 visitors per day. As for the population in this research is the consumers or the people who live around the Happy grocers have shopped more than twice. The technique of sampling is done through accidental sampling who the chosen sample is a consumer who met with researchers who shop in the Happy Supermarkets. The sample in this study is that consumers buy in the Supermarkets Happy by the taking of 100 samples. Analysis tools are used multiple regression analysis.

\section{RESULT, CONCLUSION, IMPLICATION AND LIMITATION}

\section{Characteristic Respondents}

Based on a respondent's gender, male-sex as many as 23 people and women 77 people. Respondents aged < 25 years by as much as 1 person, 25-50 people as much as 91 people, and > 50 years as many as 8 people. Respondent which has a different final education, 2-person education the last D1, 18 people last education D3, 36 people last Education Degree, 39 people last education 39, 3 people last education junior high school, and 2 the last educated people S2 (magister). 


\section{Statistic Inferential}

\section{Goodness of Fit Test or Determinants (R2)}

The coefficient of determination (R2) is a rating that measures how far the proportion of capability model in explaining the variation of free variables or predictor. Determination of coefficient of test results on the research of model structure can be seen as follows:

Tabel 1. Test Results the Coefficient of Determination (R2) Regression Model Model Summary ${ }^{b}$

\begin{tabular}{|l|r|r|r|c|}
\hline Model & \multicolumn{1}{|c|}{$\mathrm{R}$} & R Square & \multicolumn{1}{|c|}{$\begin{array}{c}\text { Adjusted R } \\
\text { Square }\end{array}$} & $\begin{array}{c}\text { Std. Error of the } \\
\text { Estimate }\end{array}$ \\
\hline 1 & $.730^{\mathrm{a}}$ & .532 & .523 & 1.11111 \\
\hline
\end{tabular}

a. Predictors: (Constant), Sales Promotion, Store Atmosphere

b. Dependent Variable: Decision Purchase

From the table above, it can be seen that the value $\mathrm{R}=0.730$ means a relationship between Store Atmosphere and Sales Promotion of $73.0 \%$. That means dealing closely. The larger the $\mathrm{R}$ means the relationship is increasingly tight. $\mathrm{R}$ Square of $53.2 \% 0532$ means factors purchase decision can be explained by the Store Atmosphere and Sales Promotion. While the remaining $46.8 \%$ can be explained by other factors not examined by this study. Adjusted R Square of 52.3\% 0523 means factors purchase decision can be explained by the Store Atmosphere and Sales Promotion. 47.7\% while the rest can be explained by other factors not examined by this study.

\section{F-Test (Test Simultaneous)}

Tabel 2. Simultaneous Test Result (Test-F) Regression Model ANOVA ${ }^{b}$

\begin{tabular}{|ll|r|r|r|r|r|}
\hline Model & & Sum of Squares & df & Mean Square & F & Sig. \\
\hline 1 & Regression & 136.357 & 2 & 68.179 & 55.225 & $.000^{\mathrm{a}}$ \\
& Residual & 119.753 & 97 & 1.235 & & \\
& Total & 256.110 & 99 & & & \\
\hline
\end{tabular}

a. Predictors: (Constant), Sales Promotion, Store Atmosphere

b. Dependent Variable: Decision Purchase

The above table reveals that $\mathrm{F}$ value calculate the significance level with 55,225 is 0000 . While the $\mathrm{F}$ tables at $95 \%$ confidence level $(\alpha=0.05)$ was 3.090 . Therefore, in both the calculation of Fhitung $>\mathrm{F}$ tables and their significance level $(0.000)<0.05$, indicating that the influence independent variable (store atmosphere and sales promotion) simultaneously is on significant purchasing decisions.

\section{The T-Test, Test the Partially}

Table. 3 Partial Test results (test-t) Hypothesis

Coefficients $^{\mathrm{a}}$

\begin{tabular}{|c|c|c|c|c|c|c|}
\hline \multirow{2}{*}{\multicolumn{2}{|c|}{ Model }} & \multicolumn{2}{|c|}{ Unstandardized Coefficients } & \multirow{2}{*}{$\begin{array}{c}\text { Standardized } \\
\text { Coefficients } \\
\text { Beta }\end{array}$} & \multirow[b]{2}{*}{$\mathrm{t}$} & \multirow[b]{2}{*}{ Sig. } \\
\hline & & $\mathrm{B}$ & Std. Error & & & \\
\hline \multirow[t]{3}{*}{1} & (Constant) & 4.316 & 1.235 & & 3.495 & .001 \\
\hline & Store Atmosphere & .038 & .025 & .132 & 1.523 & .131 \\
\hline & Sales Promotion & .365 & .040 & .802 & 9.221 & .000 \\
\hline
\end{tabular}

a. Dependent Variable: Decision Purchase 
Variables store atmosphere positively influential but not significantly to consumer decisions this looks the value $t(1,523)<t_{\text {tabel }}(1.985)$, meaning that although improved variable store atmosphere of one unit then the decision the purchase will not be reduced by 0.038 . The variable sales promotion effect in a positive and significantly to the purchasing decision, this can be seen from the level of significance (0.000) under the (smaller) 0.05. The value of ${ }^{\text {thitung }}(9.221)>t$ table (1.985) means that if the variable is increased sales promotion of one unit then the purchasing decisions of consumers will increase of 0.365 .

Based on the results of the test $\mathrm{t}$ then the formula regression equation is:

$\mathrm{Y}=\mathrm{a}+\mathrm{b}_{1} \mathrm{X}_{1}+\mathrm{b} 2 \mathrm{X}_{2}+\mathrm{e}$

$\mathrm{Y}=4,316+0,038 \mathrm{X}_{1}+0,365 \mathrm{X}_{2}+\mathrm{e}$

\section{DISCUSSION}

The influence of store atmosphere on consumer purchasing decisions

Store atmosphere effect significantly to purchasing decisions. This is supported by research conducted by Widiyanto et.al. (2014) that tests each factor on a variable store atmosphere that influence purchase decisions against together with research conducted by Syahputra and Supriyatin (2015), Nofiawaty and Beli Yuliandi (2014). it is also supported by research conducted by Sulistiorini (2017) in partial research.

\section{The influence of sales promotion on purchasing decisions}

Sales promotion has a positive influence and significantly to consumer purchasing decisions this may be a reference to the supermarket where the more vigorous and in making promotional product will attract consumers to often come and shop at self-service Happy. Promo price and product can become a mainstay in the community in the area of Sri Scissors and surrounding areas. This is in accordance with the research done Natalia (2014) that shows the research hypothesis is acceptable.

The Factor of store atmosphere and sales promotion on consumer purchasing decisions

The influence of the afternoon atmosphere and sales promotion towards purchasing decisions together mutually demonstrate a positive influence. On a Variable store atmosphere and sales promotion also shows a close relationship and this in accordance with the research Puspitasari and Tri Yuniarti (2016) that shows it has a positive influence and relation towards purchasing decisions.

\section{CONCLUSION}

Based on the results of the research on the influence of store atmosphere and sales promotion towards purchasing decisions can be drawn a conclusion that store atmosphere and sales promotion is an influential variable are positive in creating purchases decision although at variable store atmosphere is not significant. Where in this research proves that the supermarket that can attract the interest of consumers is a self-service store that has a good atmosphere with no need to change a lot of exterior, interior, store layout and interior display. However, in the sales promotion is done will make many interesting consumers to shop on the grounds. This study discusses the existence of variables variables that make the assessment that the supermarkets Happy in Srigunting succeeded in running the program promotions and store design designed by them.

\section{RECOMMANDATIONS}

Advice can be given on the basis of the results of this research to the Supermarkets Happy in Srigunting in order for the goods in the post have a clear pricing, so that consumers and customers not to guess the price in buying and didn't bother to check prices price check on a machine that is placed in the corners on a stelling cosmetics and medicines. Next on the exterior self-service should be Happy with the symbol or image so that it will give the impression of an interesting and entertaining in the community who see it. 


\section{REFERENCES}

Asnawi, Sahlan. 2007. Teori Motivasi. Jakarta: Studia Press.

Berman, Bary dan Joel R Evans. 2010. Retail Management (1 ${ }^{\text {th }}$ ed.) New Jersey: Prentice Hall.

Berman, dan Evan. 2007 Manajemen Ritel. Jakarta. Erlangga.

Kleinsteuber F. dan Sutoo S., 2007. Effective Price Strategy to Increase Your Profit. Edisi Kedua. Jakarta. PT.Damar Mulia Pustaka.

Kotler, Philip. 2001. Manajemen Pemasaran: Analisis, Perencanaan, Implementasi dan Kontrol. Jakarta: PT. Prehallindo.

Kotler, P. 2005. Manajemen Pemasaran. Jilid I dan II. Jakarta. Indeks.

Kotler, Philip. 2008. Manajemen Pemasaran Edisi 12 Jilid 2. Jakarta: Indeks

Kwan, Oky Gunawan. 2016. Pengaruh Sales Promotion dan Store Atmosphere Terhadap Impulse Buying Dengan Positive Emotion Sebagai Variabel Intervening Pada Planet Sports Tunjungan Plaza Surabaya. Jurnal Manajemen Pemasaran. Vol.10, No.1. ISSN: 1907-235X.

Mowen, John C., dan Minor, Michael. (2002). Perilaku Konsumen. Edisi 5, Jilid 2. Jakarta: Penerbit Erlangga

Natalia, Priccila dan Mumuh Mulyana. 2014. Pengaruh Periklanan Dan Promosi Penjuala Terhadap Keputusan Pembelian. Jurnal Ilmiah Manajemen Kesatuan. Vol. 2 No. 2, 2014. pp. 119-128. ISSN 2337 - 7860.

Nofiawaty and. Beli Yuliandi. 2014. Pengaruh Store Atmosphere Terhadap Keputusan Pembelian Konsumen Pada Outlet Nyenyes Palembang. Jurnal Manajemen dan Bisnis Sriwijaya. Vol.12 No.1 Maret.

Peter, J. Paul dan Donnely. 2004. Marketing. Jakarta: Erlangga.

Puspitasari, Aisyah Dewi dan Tri Yuniati. 2016. Pengaruh Store Atmosphere Dan Promotion Terhadap Keputusan Pembelian Melalui Minat Beli. Jurnal Ilmu dan Riset Manajemen. Volume 5, Nomor 1. ISSN: 2461-0593.

Ratnasari, V.A., Srikandi Kumadji, dan Andriani Kusumawati. (2015). Pengaruh Store Atmosphere Terhadap Hedonic Shopping Value dan Impulse Buying (Survei Pada Konsumen Hypermart Malang Town Square). Jurnal Administrasi Bisnis (JAB). Vol. 1 No. 1 Januari.

Rohman, Hasbi Fauzi. 2014. Pengaruh Store Atmosphere Dan Sales Promotion Terhadap Proses Keputusan Pembelian Konsumen Di Distro Oink Bandung. Skripsi. Program Studi Manajemen Fakultas Ekonomi dan Bisnis dan Manajemen Universitas Widyatama. Bandung.

Setiadi J Nugroho. 2003. Perilaku Konsumen. Salatiga, Andi

Sugiyono. 2015. Metode Penelitian Bisnis. Bandung: CV.Alfabeta

Sulistiorini, Indah. 2017. Pengaruh Store atmosphere Terhadap Keputusan Pembelian Konsumen

Pada Eramart Tenggiri Samarinda. e Journal Administrasi Bisnis. 5 (2): 511-520 ISSN 2355-5408.

Syahputra, Denny Eka dan Supriyatin. 2015. Pengaruh Store Atmosphere, Harga dan Lokasi Terhadap keputusan Pembelian Ore Premium Store. Jurnal Ilmu dan Riset Manajemen. Volume 4, Nomor 11

Utami, Christina Whidya. 2010. Manajemen Ritel. Edisi 2. Salemba Empat. Jakarta.

Widyanto, Achmad Indra, Edy Yulianto dan Sunarti. 2014. Pengaruh Store Atmosphere Terhadap Keputusan Pembelian (Survei pada Konsmen Distro Planet Surf Mall Olympic Garden Kota Malang). Jurnal Administrasi Bisnis (JAB). Vol. 14 No. 1.

Zulkarnain, Mochamad Arifin. 2018. Pengaruh Promosi Penjualan Dan Store Atmosphere Terhadap Keputusan Pembelian (Studi pada Konsumen Toko Buku Togamas Petra Surabaya). Jurnal Ilmu Manajemen. Volume 6 Nomor 1

http//: telepon.info.com visited on [14th April 2018]. 